\title{
PENGEMBANGAN MODEL PERKULIAHAN BERBASIS MASALAH PADA MATA KULIAH MANAJEMEN PENDIDIKAN MELALUI SURVEI MANAJEMEN MADRASAH
}

\author{
Asmendri \\ Program Studi Pendidikan Agama Islam Jurusan Tarbiyah STAIN Batusangkar \\ Korespondensi: Jl. Green Bariang Indah III E No. 10 Anduriang, Padang. \\ e-mail: asmendri.25@gmail.com
}

\begin{abstract}
This study aimed at describing students' ability in finding solutions of the problems dealing with managerial problems found at Islamic schools as the conducted survey. Based on the data analysis and discussion, it was found that the students' ability in finding solution was good. Students' response toward the learning process of Manajemen Pendidikan (Educational Management) subject employing Islamic school management survey in general was effective because most of students gave positive responses.
\end{abstract}

Kata kunci: pembelajaran berbasis masalah, manajemen pendidikan, dan survei manajemen madrasah

\section{PENDAHULUAN}

$\mathrm{P}$ erkuliahan yang sangat teoritis akan menyebabkan mahasiswa sulit memahami bahan ajar manajemen pendidikan secara komprehensif. Akhirnya mahasiswa cenderung menghafal dan mengerjakan tugas secara mekanistik, tanpa memahami materi dasarnya. Akibatnya skema pemikiran mahasiswa menjadi terpotong-potong dan tidak terjadi pemahaman secara komprehensif (menyeluruh). Hasil penelitian Helpern (1992:34) menunjukkan bahwa dalam perkuliahan, komprehensifan pemahaman sangat penting sehingga dapat dipahami mahasiswa secara komprehensif dibandingkan dengan banyak topik yang dipahami secara parsial. Melalui bekal pemahaman dengan sedikit materi tetapi komprehensif diharapkan mahasiswa dapat menggunakan bekal pemahaman tersebut untuk mempelajari materi lainnya. Pemahaman yang komprehensif terhadap suatu topik itulah yang diharapkan menjadi bekal ilmu pengetahuan ketika yang bersangkutan mempelajari materi lainya (Deese, 1995:17).

Perbaikan perkuliahan manajemen pendidikan perlu terus dilakukan. Kegiatan perkuliahan tidak lagi berorientasi kepada hasil semata, tetapi juga harus menekankan kepada proses. KTSP menekankan perkuliahan terpusat kepada mahasiswa bukan kepada dosen lagi. Dosen harus berpandangan bahwa perkuliahan merupakan suatu upaya untuk membantu mahasiswa mengkonstruksi pengetahuan dengan kemampuannya sendiri melalui proses internalisasi. Fungsi perkuliahan semestinya bukan suatu upaya untuk transfer informasi (pengetahuan), tetapi suatu upaya untuk 
membangun pemahaman terhadap informasi (pengetahuan).

Aktivitas mahasiswa tidak terbatas pada aktivitas menyelesaikan soal-soal rutin sesuai dengan contoh yang diberikan oleh dosen, tetapi perlu pula melibatkan berbagai aktivitas aktif yang dapat merangsang kemampuan berpikir dan kemampuan memecahkan masalah. Interaksi sosial merupakan faktor penting dalam perkuliahan manajemen pendidikan. Interaksi sosial antara mahasiswa dengan teman sebaya dan dosen selain bermanfaat dalam menambah kecakapan sosial (social skill) juga bermanfaat dalam perkembangan kognitifnya. Dalam interaksi sosial, mahasiswa dapat bersama-sama dengan teman sebayanya menyelesaikan masalah bersama, mahasiswa dapat pula menerima bantuan terbatas dari teman sebayanya yang lebih mampu atau dari orang lain (dosen). Menurut Brown dan Fermata mengemukakan (dalam Rutumanan, 2003:3) bahwa mula-mula mahasiswa mengalami kegiatan memecahkan masalah secara aktif dengan kehadiran orang lain, tetapi selanjutnya berangsur-angsur mahasiswa mampu mengerjakan sendiri (secara mandiri).

Bertolak dari uraian di atas, maka permasalahannya adalah "bagaimanakah menyusun suatu kegiatan perkuliahan sehingga dapat meningkatkan partisipasi aktif mahasiswa untuk mengikuti perkuliahan Manajemen pendidikan? Dalam menyusun kegiatan perkuliahan ini diawali dengan mengembangkan perangkat perkuliahan yang bertujuan untuk mengoptimalkan kegiatan perkuliahan dan mencari kesesuaian antara materi, kegiatan mahasiswa, alokasi waktu dan tes hasil belajar. Dengan demikian, diharapkan kegiatan perkuliahan dapat dilaksanakan secara efektif dan hasil belajar mahasiswa meningkat. Hal ini disebabkan, mahasiswa dapat menerapkan pengetahuan, bekerja memecahkan masalah, menemukan sesuatu untuk dirinya dan saling mendiskusikan masalah-masalah tersebut dengan temannya.

Berdasarkan pertimbangan di atas, sangat memungkinkan untuk diterapkan model perkuliahan berbasis masalah pada mata kuliah manajemen pendidikan ini. Oleh kerena itu merasa perlu dilakukan penelitian dengan judul "Pengembangan Model Perkuliahan Berbasis Masalah (PBM) pada Mata Kuliah Manajemen Pendidikan di STAIN Batusangkar Melalui Survei Manajemen Madrasah.

\section{KAJIAN TEORITIK}

\section{Ruang Lingkup Manajemen Pen- didikan di Madrasah}

Manajemen pendidikan secara umum diartikan sebagai proses pengerahan dan pengintegrasian segala sesuatu, baik personel, spiritual maupun material yang bersangkut paut dengan pencapaian tujuan pendidikan. Jadi di dalam proses manajemen pendidikan, segenap usaha orang-orang yang terlibat di dalam proses pencapaian tujuan pendidikan itu diintegrasikan, diorganisasi dan dikoordinasikan secara efektif, dan semua materi yang diperlukan dan yang telah ada dimanfaatkan secara efisien.

Masalah yang akan disurvei oleh mahasiswa hanya ditetapkan pada materi delapan aspek manajemen pendidikan di madrasah seperti (1) manajemen kurikulum, (2) manajemen murid, (3) manajemen personel, (4) manajemen tatalaksana, (5) manajemen sarana pendidikan, (6) manajemen keuangan sekolah, (7) manajemen organisasi sekolah, dan (8) manajemen hubungan sekolah dengan masyarakat.

\section{Perkuliahan Manajemen Pendidikan dengan PBM}

PBM adalah suatu pengembangan pendekatan pembelajaran yang terpusat pada mahasiswa (student centered). Pro- 
ses perkuliahan seperti ini merupakan pembelajaran yang menganut aliran konstruktivisme bahwa proses pembelajaran dengan pendekatan konstruktivis lebih menekankan pada aktivitas peserta didik dan menjadikan peserta didik lebih banyak berinteraksi dengan obyek dan peristiwa, sehingga peserta didik memperoleh pemahaman. Peran dosen/guru dalam hal ini hanya sebagai fasilitator bukan pentransfer pengetahuan. Teori konstruktivisme ini lahir dari gagasan Piaget dan Vygotsky yang dengan sederhana beranggapan bahwa pengetahuan itu merupakan hasil konstruksi (bentukkan) kognitif melalui kegiatan seseorang.

Pada awalnya PBM ini dikembangkan di fakultas kedokteran untuk melatih para dokter dalam menyelesaikan masalah-masalah medis. Namun PBM tidak hanya dikembangkan dalam dunia kedokteran, dalam mata kuliah manajemen pendidikan pun diperlukan untuk memecahkan masalah-masalah manajemen pendidikan terutama di sekolah. Perkuliahan manajemen pendidikan tidak hanya menghafal teori-teori saja, namun mahasiswa dituntut untuk memahami konsep dan membangun pemahaman. Mahasiswa juga harus mampu melakukan survei ke madrasah melihat pelaksanakan manajemen pendidikan di madrasah. Dengan survei itu mahasiswa dapat melihat bagaimana penerapan teori manajemen pendidikan tersebut di madarasah dan mahasiswa juga dapat memecahkan masalah jika ditemukan ketidaksesuain antara teori dengan praktek/penerapannya.

PBM mencoba untuk membuat mahasiswa lebih bertanggung jawab dalam perkuliahan daripada sekedar menjadi penerima informasi yang pasif. Mahasiswa didik untuk bertanya, menemukan informasi relevan, dan merancang solusi-solusi untuk masalah open ended dan masalah yang tidak lengkap (ill-structured problem).

Langkah-langkah pemecahan masalah dalam pembelajaran PBM paling sedikit ada delapan tahapan (Pannen, 2001), yaitu: (1) mengidentifikasi masalah, (2) mengumpulkan data, (3) menganalisis data, (4) memecahkan masalah berdasarkan pada data yang ada dan analisisnya, (5) memilih cara untuk memecahkan masalah, (6) merencanakan penerapan pemecahan masalah, (7) melakukan ujicoba terhadap rencana yang ditetapkan, dan (8) melakukan tindakan (action) untuk memecahkan masalah. Empat tahap yang pertama mutlak diperlukan untuk berbagai kategori tingkat berfikir, sedangkan empat tahap berikutnya harus dicapai bila pembelajaran dimaksudkan untuk mencapai keterampilan berfikir tingkat tinggi (higher order thinking skills). Dalam proses pemecahan masalah sehari-hari, seluruh tahapan terjadi dan bergulir dengan sendirinya, demikian pula keterampilan seseorang harus mencapai seluruh tahapan tersebut.

Lebih lanjut Arends (2004) merinci langkah-langkah pelaksanaan PBM dalam pengajaran. Arends mengemukakan ada 5 fase (tahap) yang perlu dilakukan untuk mengimplementasikan PBM. Fase-fase tersebut merujuk pada tahap-tahapan praktis yang dilakukan dalam kegiatan pembelajaran dengan PBM sebagaimana disajikan pada Tabel 1 . 
Tabel 1. Sintaks Problem Based Learning

Fase-fase

Fase $1:$ memberikan orientasi tentang permasalahannya kepada peserta didik.

\section{Perilaku pendidik}

Pendidik menyampaikan tujuan pembelajaran, mendeskripsikan berbagai kebutuhan logistik penting dan memotivasi peserta didik untuk terlibat dalam kegiatan mengatasi masalah.

Fase 2 : mengorganisasikan peserta didik untuk meneliti

Pendidik membantu peserta didik mendefinisikan dan mengoragnisasikan tugas-tugas belajar terkait dengan permasalahannya.

Fase 3 : membantu investigasi mandiri Pendidik mendorong peserta didik untuk mendapatkan dan kelompok informasi yang tepat, melaksanakan eksperimen, dan mencari penjelasan dan solusi.

Fase 4 : Mengembangkan dan menyajikan hasil karya
Pendidik membantu peserta didik dalam merencanakan dan menyiapkan artefak-artefak yang tepat, seperti laporan, rekaman video, dan model-model serta membantu mereka untuk menyampaikannya kepada orang lain.

Fase 5 : menganalisis dan mengevaluasi Pendidik membantu peserta didik melakukan refleksi proses mengatasi masalah terhadap investigasinya dan proses-proses yang mereka gunakan.

\section{METODE PENELITIAN}

Jenis penelitian ini dikategorikan penelitian pengembangan (developmental research), karena penelitian ini bertujuan mengembangkan perangkat perkuliahan dan selanjutnya perangkat yang dikembangkan diimplementasikan di kelas. Penelitian ini juga termasuk penelitian tindakan kelas karena dilakukan untuk memperbaiki kualitas perkuliahan dan kinerja mahasiswa dalam mengikuti perkuliahan manajemen pendidikan. Dengan demikian penelitian ini termasuk penelitian pengembangan dan penelitian tindakan.

Penelitian ini dilaksanakan dalam dua tahap, yakni tahap pengembangan perangkat perkuliahan dan tahap implementasi perangkat di kelas. Pengembangan perangkat perkuliahan berorientasi PBM ini menggunakan Four-D Model yang dikemukakan oleh
Thiagarajan, dan Semmel (dalam Kusaeri, 2008: 4). Proses pengembangan perangkat perkuliahan terdiri atas empat tahap yaitu define (menetapkan), design (merancang), develop (mengembangkan), dan disseminate (menyebarkan). Namun pada penelitian ini hanya direncanakan sampai tahap mengembangkan. Pada tahap pengembangan perangkat perkuliahan kegiatan yang dilaksanakan adalah: (1) menetapkan aspek-aspek manajemen pendidikan yang akan disurvey, (2) merancang proses perkuliahan guna meningkatkan kemampuan dan keterampilan mahasiswa sebelum ke lapangan, (3) mempersiapkan segala hal yang berkaitan dengan administrasi untuk mendukung kelancaran survei.

Pada tahap implementasi di kelas, akan diadakan seminar hasil survei. Tujuan dari kegiatan ini adalah untuk melihat kemampuan mahasiswa dalam 
menemukan dan memecahkan masalah yang berkaitan dengan pelaksanaan manajemen pendidikan di madrasah.

\section{HASIL PENELITIAN}

Penelitian ini dilakukan pada semester genap tahun ajaran 2010/2011. Responden adalah mahasiswa prodi Tadris Biologi semester IV STAIN Batusangkar yang mengikuti perkuliahan manajemen pendidikan dengan jumlah 45 orang mahasiswa. Hasil penelitian membahas tentang (1) kemampuan mahasiswa dalam mencarikan solusi terhadap masalah manajemen madrasah yang ditemui setelah melaksanakan survei, (2) respon mahasiswa terhadap kegiatan perkuliahan Manajemen Pendidikan dengan menggunakan PBM melalui survei manajemen madrasah, dan (3) kendala-kendala yang muncul dalam kegiatan perkuliahan dengan mengggunakan PBM melalui survei manajemen madrasah. Hasill penelitian masing-masing aspek tersebut dipaparkan sebagai berikut.

\section{Kemampuan Mahasiswa dalam Men- carikan Solusi Terhadap Masalah Manajemen Madrasah yang Ditemui Setelah Melaksanakan Survei}

Penelitian ini dilaksanakan dalam dua tahap, yakni tahap pengembangan perangkat perkuliahan dan tahap implementasi perangkat di kelas. Pada tahap pengembangan perangkat perkuliahan kegiatan yang dilaksanakan adalah: (1) menetapkan aspek-aspek manajemen pendidikan yang akan disurvei, (2) merancang proses perkuliahan guna meningkatkan kemampuan dan keterampilan mahasiswa sebelum ke lapangan, (3) mempersiapkan segala hal yang berkait- an dengan administrasi untuk mendukung kelancaran survei. Pada tahap implementasi di kelas, akan diadakan seminar hasil survei. Tujuan dari kegiatan ini adalah untuk melihat kemampuan mahasiswa dalam menemukan dan memecahkan masalah yang berkaitan dengan pelaksanaan manajemen pendidikan di madrasah.

Kemampuan mahasiswa dalam mencarikan solusi terhadap masalah manajemen madrasah yang ditemui terlihat pada tahap implementasi di kelas, dalam bentuk seminar hasil survey. Sebelum survei, mahasiswa dibekali dengan lembar observasi supaya aspekaspek manajemen yang akan dilihat lebih fokus dan memudahkan untuk mendeteksi masalah manajemen yang dijumpai di madrasah. Mengantisipasi kendala yang akan dihadapi di madrasah, mahasiswa dibekali dengan surat pengantar dari STAIN Batusangkar untuk diizinkan melaksanakan observasi. Disamping itu, pihak madrasah juga diminta memberikan surat keterangan bahwa mahasiswa yang bersangkutan telah selesai melaksanakan observasi, sebagai bukti kalau observasi benar-benar dilaksanakan oleh mahasiswa.

Hasil laporan observasi dan seminar laporan hasil menunjukkan bahwa mahasiswa berhasil dalam merancang dan menyajikan karya berupa laporan hasil observasi pelaksanaan manajemen di madrasah. $80 \%$ mahasiswa bisa melakukan evaluasi terhadap pelaksanaan manajemen di madrasah dan solusi untuk pemecahan masalahnya. Keberhasilan perkuliahan berbasis masalah dikatakan berhasil baik atau tuntas jika skor mahasiswa $\geq 70 \%$. Lengkapnya dapat dilihat pada Tabel 4.1 berikut ini. 
Tabel 2 Kemampuan mahasiswa dalam mencarikan solusi terhadap masalah manajemen madrasah

\begin{tabular}{|c|c|c|c|}
\hline No & Aspek yang Diamati & $\begin{array}{l}\text { Rata-Rata } \\
\text { Ketuntasan }\end{array}$ & Kategori \\
\hline 1 & $\begin{array}{l}\text { Merancang dan menyajikan karya berupa laporan } \\
\text { observasi, aspek yang dinilai: } \\
\text { a) Sistematika penulisan } \\
\text { b) Kelengkapan data } \\
\text { c) Analisis hasil (Melakukan refleksi/evaluasi } \\
\text { terhadap masalah pelaksanaan manajemen di } \\
\text { madrasah dan solusi pemecahan masalah) } \\
\text { d) Kesimpulan }\end{array}$ & $\begin{array}{l}84 \% \\
100 \% \\
80 \% \\
80 \%\end{array}$ & $\begin{array}{l}\text { Baik/tuntas } \\
\text { Baik/tuntas } \\
\text { Baik/tuntas } \\
\text { Baik/tuntas }\end{array}$ \\
\hline 2 & $\begin{array}{l}\text { Presentasi (seminar ) laporan hasil survey. } \\
\text { a) Kerjasama kelompok } \\
\text { b) Kemampuan menjelaskan masalah dan solusi } \\
\text { yang ditawarkan/kemukakan } \\
\text { c) Kemampuan mempertahankan argumentasi }\end{array}$ & $\begin{array}{l}80 \% \\
80 \% \\
80 \%\end{array}$ & $\begin{array}{l}\text { Baik/tuntas } \\
\text { Baik/tuntas } \\
\text { Baik/tuntas }\end{array}$ \\
\hline
\end{tabular}

\section{Respon Mahasiswa terhadap Kegiatan Perkuliahan}

Berdasarkan respon mahasiswa terhadap model perkuliahan berbasis masalah diperoleh data respon mahasiswa mengenai; responnya terhadap perkuliahan, motivasinya dalam belajar, keberaniannya bertanya terhadap masalah yang dihadapi, keaktifannya dalam kelompok, pemahaannnya terhadap materi perkuliahan dengan model PBM, hubungannya dengan teman, waktu yang dibutuhkan dalam melaksanakan observasi, pembagaian kelompok dan bagaimana jika model PBM diterapkan pada mata kuliah lain. Respon yang diberikan mahasiswa melalui angket terhadap Model PBM ini dapat dilihat pada Tabel 3.

Tabel 3 Pendapat mahasiswa tentang perkuliahan PBM pada mata kuliah Manajemen Pendidikan

\begin{tabular}{|c|l|c|c|c|c|}
\hline NO & \multicolumn{1}{|c|}{ Aktivitas } & \multicolumn{3}{|c|}{ Tingkat Antusias Siswa/mahasiswa } \\
\cline { 3 - 6 } & \multicolumn{1}{|c|}{$\begin{array}{c}\text { Sangat } \\
\text { Setuju }\end{array}$} & Setuju & $\begin{array}{c}\text { Kurang } \\
\text { Setuju }\end{array}$ & $\begin{array}{c}\text { Tidak } \\
\text { Setuju }\end{array}$ \\
\hline 1 & $\begin{array}{l}\text { Belajar Manajemen Pendidikan } \\
\text { dengan model Perkuliahan Berbasis } \\
\text { Masalah lebih menyenangkan. }\end{array}$ & $\begin{array}{c}10 \\
(22.2 \%)\end{array}$ & $\begin{array}{c}35 \\
(77.8 \%)\end{array}$ & - & - \\
\hline 2 & $\begin{array}{l}\text { Belajar kelompok model Perkuliahan } \\
\text { Berbasis Masalah dapat memotivasi } \\
\text { saya dalam belajar Manajemen }\end{array}$ & $\begin{array}{l}11 \\
\text { Pendidikan }\end{array}$ & $\begin{array}{c}33 \\
(24.4 \%)\end{array}$ & $\begin{array}{c}(73.3 \%) \\
(2.2 \%)\end{array}$ & - \\
\hline 3 & $\begin{array}{l}\text { Dengan belajar kelompok model } \\
\text { Perkuliahan Berbasis Masalah, saya } \\
\text { tidak malu bertanya pada teman } \\
\text { sekelompok. }\end{array}$ & $\begin{array}{c}13 \\
(28.9 \%)\end{array}$ & $\begin{array}{c}25 \\
(55.5 \%)\end{array}$ & $\begin{array}{c}7 \\
(15.5 \%)\end{array}$ & - \\
\hline 4 & $\begin{array}{l}\text { Semua anggota kelompok aktif } \\
\text { menyelesaikan masalah-masalah } \\
\text { dalam Manajemen Pendidikan. }\end{array}$ & $\begin{array}{c}13 \\
(28.9 \%)\end{array}$ & $\begin{array}{c}13 \\
(28.9 \%)\end{array}$ & $\begin{array}{c}18 \\
(40 \%)\end{array}$ & $\begin{array}{c}1 \\
(2.2 \%)\end{array}$ \\
\hline 5 & Jika ada yang tidak bisa memecahkan & 26 & 14 & 4 & 1 \\
\hline
\end{tabular}




\begin{tabular}{|c|l|c|c|c|c|}
\hline & masalah, bertanya pada dosen & $(57.8 \%)$ & $(31.1 \%)$ & $(8.9 \%)$ & $(2.2 \%)$ \\
\hline 6 & $\begin{array}{l}\text { Pembagian kelompok dilakukan } \\
\text { dengan kemampuan } \\
\text { mahasiswa/mahasiswa yang beragam. }\end{array}$ & $\begin{array}{c}17 \\
(37.8 \%)\end{array}$ & $\begin{array}{c}11 \\
(24.4 \%)\end{array}$ & $\begin{array}{c}15 \\
(33.3 \%)\end{array}$ & $\begin{array}{c}2 \\
(4.44 \%)\end{array}$ \\
\hline 7 & $\begin{array}{l}\text { Dengan belajar kelompok model } \\
\text { Perkuliahan Berbasis Masalah, saya } \\
\text { lebih mengerti Manajemen }\end{array}$ & $\begin{array}{c}13 \\
(28.9 \%)\end{array}$ & $\begin{array}{c}31 \\
(68.9 \%)\end{array}$ & $\begin{array}{c}(2.2 \%) \\
\text { Pendidikan. }\end{array}$ & - \\
\hline 8 & $\begin{array}{l}\text { Dengan belajar kelompok model } \\
\text { Perkuliahan Berbasis Masalah, saya } \\
\text { lebih akrab dengan teman. }\end{array}$ & $\begin{array}{c}13 \\
(28.9 \%)\end{array}$ & $\begin{array}{c}23 \\
(51.1 \%)\end{array}$ & $\begin{array}{c}(7.8 \%) \\
(2.2 \%)\end{array}$ \\
\hline 9 & $\begin{array}{l}\text { Waktu yang diberikan dalam observasi } \\
\text { perlu ditambah. }\end{array}$ & $\begin{array}{c}20 \\
(44.4 \%)\end{array}$ & $\begin{array}{c}24 \\
(53.3 \%)\end{array}$ & - & 1 \\
\hline 10 & $\begin{array}{l}\text { Belajar kelompok model Perkuliahan } \\
\text { Berbasis Masalah, sebaiknya } \\
\text { digunakan juga pada mata perkuliahan } \\
\text { lain. }\end{array}$ & $\begin{array}{c}11 \\
(244 \%)\end{array}$ & $\begin{array}{c}26 \\
(57.8 \%)\end{array}$ & $\begin{array}{c}7 \\
(15.5 \%)\end{array}$ & \begin{tabular}{c}
$(2.2 \%)$ \\
\hline
\end{tabular} \\
\hline
\end{tabular}

Berdasarkan Tabel 3 terlihat ratarata mahasiswa menjawab setuju dengan kegiatan perkuliahan yang diterapkan. Mereka makin termotivasi dalam belajar dan aktif bekerja sama dengan temannya dalam memecahkan masalah yang ditemui di lapangan. Walaupun masih ada sebagai mahasiswa menyatakan masih ada temannya yang tidak peduli/kurang aktif dalam kelompok. Namun begitu, model perkuliahan ini membuat mereka semakin akrab, tidak malu bertanya jika mengalami kendala baik kepada dosen maupun teman sebaya, sehingga mereka makin mengerti dengan materi perkuliahan yang diajarkan/dipelajari. Hampir $90 \%$ mahasiswa menyukai cara dosen mengajar dengan menggunakan model PBI ini.

Namun demikian ada beberapa hal yang kurang disetujui oleh sebagian besar mahasiswa, yakni pembagian kelompok yang dirasa masih belum memuaskan. Walaupun mahasiswa dibagi secara acak berdasarkan nomor tempat duduk mereka, tetapi masih ada yang merasa kurang adil. Ini terlihat dari jawaban yang diberikan baik terhadap angket dalam bentuk skala likert maupun pertanyaan terbuka. 55\% lebih menyatakan kurang setuju jika pembagian kelompok dinyatakan berdasarkan kemampuan mahasiswa yang beragam.
Ada yang menyatakan beberapa kelompok terdiri atas mahasiswa yang pintar-pintar saja dan berdasarkan teman dekat. Disamping hal ini, waktu observasi yang sempit juga menjadi kendala yang mereka hadapi di lapangan, sehingga hampir sebagian besar mahasiswa menyatakan setuju jika waktu observasinya ditambah. Setelah mereka mengalami/menjalani perkuliahan model PBM, sebagian besar mahasiswa setuju model perkuliahan ini diterapkan pada perkuliahan lain, terutama matakuliah yang berhubungan dengan terapan di lapangan.

\section{PEMBAHASAN}

Mahasiswa sudah berhasil menganalisa/ mengenali masalah dalam pelaksanaan manajemen pendidikan di madrasah. Hal ini bisa dilihat dari keterampilan mahasiswa melaksanakan kegiatan observasi, yang diawali dengan mendatangi madrasah dan mengurus perizinannya, mengidentifikasi masalah dan menganalisis, melakukan refleksi/evaluasi terhadap masalah pelaksanaan manajemen di madrasah dan mencarikan solusi pemecahan masalah tersebut. Selanjutnya membuat kesimpulan dan pada akhirnya laporan tersebut diseminarkan di kelas. Walaupun pada 
laporan observasi masih ada análisis masalah dan solusi yang dikemukakan belum tepat, tetapi dari keseluruhan hasil yang diperoleh sangat memuaskan/baik. Sedangkan hasil seminar, dimana setiap kelompok menampilkan hasil observasi mereka dihadapan teman-temannya menunjukkan hasil yang juga sangat memuaskan/baik. Hampir semua mahasiswa bisa mempertahankan argumentasi mereka dalam memberikan solusi terhadap masalah yang ditemukan dilapangan. Kelompok yang tampil maupun pendengar bisa berpikit secara kritis dalam menanalisis masalah yang terjadi.

Berdasarkan respon mahasiswa terhadap model PBM diperoleh bahwa respon mahasiswa sangat positif. Tidak ada dari mahasiswa yang menyatakan kurang setuju dan tidak setuju diterapkannya model ini. Selama perkuliahan/pembelajaran mahasiswa tampak antusias dan senang dalam belajar. Positifnya respon mahasiswa terhadap model PBM. disebabkan dapat bekerja sama dalam menyelesaikan masalah, tidak malu bertanya, lebih akrab, dan suasana tidak menegangkan. Mahasiswa dengan kemampuan tinggi merasa senang dapat membantu teman satu kelompok yang kurang memahami, sehingga ada rasa puas dapat membantu temannya yang kurang mengerti. Sedangkan mahasiswa berkemampuan rendah merasa senang dapat bantuan penjelasan materi dari teman satu kelompok dan tidak malu bertanya. Biasanya kalau ada yang kurang paham, disimpan dalam hati, tidak berani bertanya kepada dosen. Adanya rasa senang mahasiswa dalam mengikuti pembelajaran dapat menyebabkan berpikir lebih tenang atau tidak tegang sehingga mahasiswa dapat menyelesaikan tugas dengan baik dan pemahaman materi dapat lebih optimal.
Berdasarkan deskripsi kendalakendala dalam proses perkuliahan PBM yaitu; terbatasnya waktu dalam melaksanakan observasi ke madrasah, karena berbarengan dengan jadwal kuliah yang lain; ada kelompok yang mendapat madrasah yang jauh dari tempat tinggalnya; dan masih ada beberapa madrasah yang kurang memberi respon terhadap kedatangan mahasiswa untuk melaksanakan observasi. Misalnya kepala madrasah yang selalu tidak ada di tempat, dan sedikit memberi keterangan, sikap para guru yang acuh tak acuh. Salah satunya mungkin disebabkan jadwal observasi yang berdekatan dengan jadwal UN, sehingga kesibukan madrasah menjadi meningkat.

\section{KESIMPULAN}

Berdasarkan hasil analisis data dan pembahasan dapat disimpulkan bahwa kemampuan mahasiswa dalam mencarikan solusi terhadap masalah manajemen madrasah yang ditemui setelah melaksanakan survei sudah baik. Respon mahasiswa terhadap kegiatan perkuliahan Manajemen Pendidikan dengan menggunakan PBM melalui survei manajemen madrasah secara umum sudah efektif karena sebagian besar mahasiswa memberi respon yang positif. Berarti pengembangan model PBM sangat cocok diterapkan pada matakuliah manajemen pendidikan melalui survei manajemen madrasah. Jika dihubungkan dengan kendala-kendala yang muncul dalam kegiatan perkuliahan dengan menggunakan PBM melalui survei manajemen madrasah ini adalah keterbatasan waktu dan kurangnya respon dari pihak madrasah. 


\section{DAFTAR RUJUKAN}

Arends, R.I. (1997). Classroom Instructional and Management. New York: McGraw-Hill Companies Inc.

Asmendri. 2008. Pengantar Studi Manajemen Pendidikan. Batusangkar: STAIN Batusangkar Press

Deese, James; Hutse, Stewart; \& Egeth, Howard. 1995. The Psychology of Learning. Tokyo: Mc Graw Hill Kogakujha, ltd.

Depdiknas. (2003). Pengajaran Berdasarkan Masalah. Jakarta: Departemen Pendidikan Nasional.

Dods, R. F., 1996. A Problem-Based Learning Design for teaching Biochemistry. Journal of Chemical Education, 73(3), 252-258.

E. Mulyasa. (2003). Menjadi Kepala Sekolah Profesional. Bandung: Remaja Rosdakarya.

Hadari Nawawi. (1981). Administrasi Pendidikan. Jakarta: Gunung Agung.

Harris, Ben M. (1975). Supervisory Behavior in Education. New Jersey: Prentice-Hall, Inc.

Helpern, Diane,F. (Ed). 1992. Enhanching Thinking Skills in The Sciences and Mathematics. New
Jersey: Lawrence Erlbaum Asociates, Publshers.

Hoy, Wayne $\mathrm{K}$ and Miskel, Cecil G (2001). Educational Administration: Theory, Research and Practice. New York: McGrawHill.

Mayer, R.E. 1983. Thinking, Problem Solving, and Cognition. New York: Freeman.

Pannen, P, dkk. 2001. Konstruktivis dalam Pembelajaran. Jakarta: PAU Depdiknas.

Rutumanan, T. (2003). Pengembangan Model Pembelajaran Interaktif dengan Setting Kooperatif (PISK) dan Pengaruhnya Terhadap Hasil Belajar Matematika Siswa/mahasiswa SLTP di Kota Ambon. Disertasi Doktor.

Torrance, E.P \& Khatena, J. (1976). Khatena-Torrance Creative Perception Inventory. Chicago: Stoelting Company

Tuckman, Bruce, W. 1978. Conducting Educational Research. Second Edition. New York: Harcourt Brace Jovanovich.

Woods, D. R. 1996. Problem-based learning: how to gain the most from PBM. Canada: McMaster University Bookstore.

\section{Daftar Indeks}

madrasah, 173, 104, 105, 107, 108, 110,

111

manajemen, $173,104,105,106,107,108$,

110,111 pembelajaran, 173, 105, 106, 110

pendidikan, 173, 104, 105, 107, 110, 111

survei, 173, 105, 107, 111 